\title{
ANALISIS PROFIL WISATAWAN MANCANEGARA YANG KELUAR MELALUI PINTU SOEKARNO HATTA DAN NGURAH RAI Veronika Juwita Hapsari ${ }^{1}$, Chaikal Nuryakin ${ }^{2}$
}

\author{
${ }^{1}$ Asisten Deputi Pengembangan Pemasaran I Regional IV \\ Kementerian Pariwisata \\ Gd. Sapta Pesona lt.4 J1. Medan Merdeka Barat no. 17 Jakarta Pusat \\ ve_hapsari@yahoo.com \\ ${ }^{2}$ Magister Perencanaan Ekonomi dan Kebijakan Publik \\ Universitas Indonesia \\ Salemba-Jakarta Pusat
}

Diterima: 8 April 2019. Disetujui: 25 September 2019. Dipublikasikan: 30 September 2019

\begin{abstract}
Abstrak
Bandara Ngurah Rai di Bali dan Bandara Soekarno-Hatta di Jakarta merupakan pintu masuk udara yang berkontribusi paling besar dalam menyumbang kunjungan wisatawan mancanegara (wisman) ke Indonesia. Passenger Exit Survey (PES) yang dilakukan pada ke-dua pintu tersebut belum mampu menjelaskan bagaimana profil wisatawan yang sebenarnya berkunjung ke Bali dan Jakarta. Dengan mengolah kembali data PES menggunakan analisis binomial logistik, kajian ini memberikan gambaran tentang tingkat dominasi profil wisman yang berkunjung ke dua Provinsi tersebut. Kajian ini berhasil mengidentifikasi bahwa, wisman yang memilih Bali sebagai provinsi yang dikunjunginya cenderung untuk memiliki profil sebagai berikut: berjenis kelamin wanita, berasal dari Asia dan Oceania, dan cenderung first timer. Wisman tersebut cenderung berprofesi sebagai bussinessman dan memiliki tujuan berkunjung ke Bali untuk liburan. Berbeda dengan wisman yang mengunjungi Bali dan provinsi lainnya, wisman tersebut cenderung memiliki profil sebagai berikut: berjenis kelamin laki-laki, berasal dari Timur Tengah dan Eropa, cenderung merupakan repeater yang didominasi oleh kunjungan bisnis dan dinas. Preferensi media wisman yang mengunjungi Bali didominasi oleh media radio, internet, leaflet, dan tourism board. Untuk wisatawan yang mengunjungi provinsi selain Bali didominasi oleh majalah dan rekomendasi dari teman.
\end{abstract}

(C) 2019 Asdep Industri dan Regulasi Pariwisata

Kata Kunci: Wisatawan Mancanegara, profil, demografi, psikografi, penilaian destinasi.

\begin{abstract}
Ngurah Rai Airport (Bali) and Soekarno-Hatta Airport (Jakarta) are the most contributed entry gate to tourist visits to Indonesia. Passenger Exit Survey (PES) conducted at those airports has not been able to explain the tourists' profile who visit Bali and Jakarta. By reprocessing PES data using binomial logistics analysis, this study provides a an international tourist profile overview of the dominance level who visits them. The study successfully identified that, tourists who chose Bali as the province they visited tended to have the following profile: female, originating from Asia and Oceania, and tending to be a first timer.
\end{abstract}


These tourists tend to work as business people and have the purpose of visiting Bali for a vacation. Unlike foreign tourists who visit Bali and other provinces, these tourists tend to have the following profile: male, originating from the Middle East and Europe, tend to be repeaters dominated by business and official visits. The preferences of foreign tourists visiting Bali are dominated by radio, internet, leaflets, and tourism boards. Tourists who visit other provinces are dominated by magazines and recommendations from friends.

Keywords: Overseas tourists, profile, demographics, psychography, destination assessment.

\section{PENDAHULUAN}

Pariwisata menjadi salah satu sektor industri di sektor jasa yang mengalami perkembangan yang sangat cepat (Tang \& Tan, 2014) serta menjadi sektor kunci dalam pengembangan ekonomi dan pembukaan lapangan kerja (WWTC, 2017). Di Indonesia, sektor pariwisata telah dirintis sebagai sektor strategis melalui kampanye Visit Indonesia Year 1991 dan ditetapkan sebagai sektor prioritas pembangunan dalam Nawa Cita 2014-2019 yang tertuang dalam Renstra Kementerian Pariwisata 20152019(Kementerian Pariwisata, 2015).

Peran sektor pariwisata sebagai sektor strategis prioritas pembangunan dapat dilihat dari kontribusi nyata sektor pariwisata dalam perekonomian. Menurut data Kementerian Pariwisata dalam Nesparnas 2017, devisa dari sektor pariwisata terus mengalami peningkatan pada tahun 2016 sebesar 13,48 milyar USD dan sebesar 15,20 milyar USD pada tahun 2017, bahkan ketika jenis komoditas lain mengalami penurunan (Tantowi, Baruddin, dan Suryani, 2017)

Pasar pariwisata internasional mengalami peningkatan dari tahun ke tahun karena perkembangan dunia transportasi dengan ada low cost carriers (LCC) yang mendukung mobilitas pariwisata (Donzelli, 2010). Perkembangan pasar ini ditunjukan dengan adanya peningkatan jumlah outbound di seluruh dunia pada periode 1995-2016 18 yaitu 62 juta perjalanan pada tahun 1995 meningkat menjadi lebih dari 1,4 milyar perjalanan pada tahun 2016 (World Bank, 2018).

Pasar pariwisata Indonesia juga mengalami pertumbuhan dari tahun ke tahun seperti ditunjukan pada Grafik 1.2. Jika dibandingkan dengan jumlah outbond internasional, wisatawan yang mengunjungi Indonesia pada tahun 2016 berkisar $0.79 \%$ dari total outbound dunia. Hal ini menunjukan bahwa potensi pasar pariwisata Indonesia masih besar dan kemungkinan bisa ditingkatkan lagi.

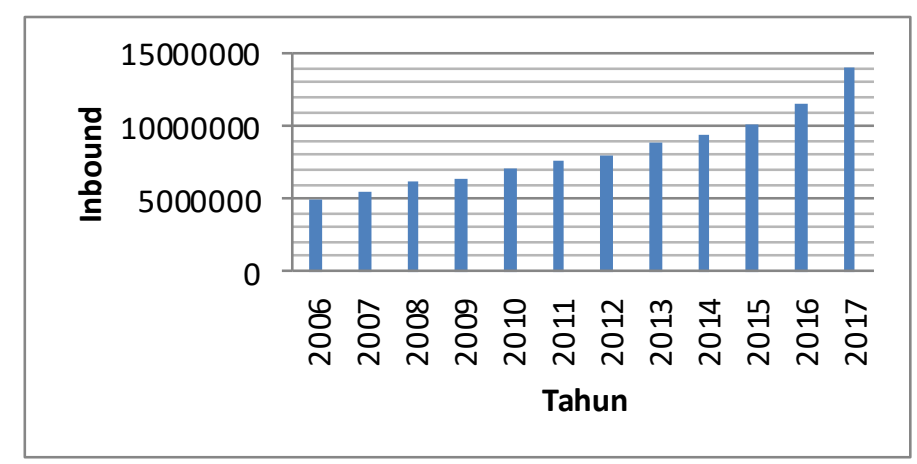

Gambar 1. Jumlah Inbound Indonesia Tahun 2006-2017 Sumber: Statistik Kunjungan Wisatawan Mancanegara 2017, BPS (2018)

Dari sisi supply, pariwisata Indonesia memiliki potensi yang beragam di seluruh wilayah Indonesia. Potensi pariwisata dikemas sedemikian rupa menjadi produk pariwisata mulai dari wisata alam (wisata bahari, ekowisata, wisata petualangan), wisata budaya (wisata warisan budaya dan sejarah, wisata belanja dan kuliner, 
wisata kota dan desa) serta wisata buatan manusia (wisata MICE, olahraga, dan objek wisata terintegrasi. Beragamnya produk pariwisata Indonesia menjadi daya tarik bagi wisatawan utuk berwisata sesuai minat yang digemarinya.

Faktanya, potensi pariwisata Indonesia dari Sabang sampai Merauke masih belum dimanfaatkan secara maksimal. Hingga saat ini, destinasi wisata Indonesia yang sudah berhasil menembus pasar internasional hanya Bali. Bali menjadi pusat dan icon pariwisata Indonesia, padahal daerah lain juga berpotensi untuk dikembangkan menjadi destinasi wisata yang bertaraf internasional sehingga bisa menjadi mesin penggerak perekonomian.

Pengembangan potensi pariwisata di wilayah lain selain Bali menjadi penting untuk memberikan alternatif destinasi pariwisata bagi wisatawan. Dengan adanya destinasi alternatif selain Bali, destinasi unggulan Indonesia tidak hanya terpaku pada Bali.

Pengembangan potensi pariwisata melalui pembangunan kepariwisataan nasional didukung dengan adanya Peraturan Pemerintah No.50 tahun 2011 tentang Rencana Induk Pembangunan Pariwisata Nasional 2010-2025. Pembangunan kepariwisataan nasional ini mencakup pengembangan destinasi pariwisata, industri pariwisata, pemasaran pariwisata, dan kelambagaan kepariwisataan. Salah satu pengembangan destinasi yang dilakukan pemerintah (Kementerian Pariwisata) adalah pembangunan "10 Bali Baru" sebagai destinasi unggulan yang menjadi alternatif selain Bali sehingga meningkatkan daya saing dalam industri pariwisata.

Daya saing dalam industri pariwisata memicu pertumbuhan segmen pasar baru (Ramkissoon, Uysal \& Brown, 2011). Luasnya segmen pasar baru membuat pemasar harus fokus pada target market tertentu. Penelitian dalam menentukan segmentasi pariwisata berfokus pada pengembangan profil segmentasi wisatawan dan memahami serta mempredikasi perilaku turis di masa yang akan datang (Tkaczynski, RundleThiele, \& Beaumont, 2009). Penelitian ini bertujuan untuk mendapatkan profil wisman yang mengunjungi destinasi Bali dan tidak mengunjungi Bali (non-Bali). Dengan mengetahui profil wisman, pengembangan pariwisata di destinasidestinasi tersebut akan dapat berfokus pada selera pasar sehingga lebih menarik minat wisatawan.

Dalam proses identifikasi segmen pasar dalam pemilihan target marketing, faktor demografi berpengaruh signifikan karena akan membentuk sistem nilai yang dimiliki seorang individu (Kahle \& Madrigal, 1994). Hal inilah yang membuat faktor psikografis juga relevan dalam proses identifikasi profil segmentasi pasar (Veisten, Lindberg, Grue, \& Haukeland, 2014) yang meliputi nilai dan sikap pribadi yang memengaruhi perilaku dan bisa menjelaskan permintaan pariwisata dan perilaku turis (Kamakura \& Mazzon, 1991; Muller, 1991; Kamakura \& Novak, 1992; Madrigal \& Kahle, 1994; Mehmetoglu, Hines, Graumman, \& Greibrokk, 2010).

\section{Kajian Literatur}

Sejak tahun 1950an, telah banyak penelitian yang dikembangkan untuk memahami faktor-faktor yang mempengaruhi arus pariwisata internasional. Jumlah penentu permintaan potensial memang sangat besar (Keintz, 1968). Mikulicz (1983) mengelompokan faktor-faktor yang mempengaruhi permintaan pariwisata ke dalam 3 kelompok, yaitu:

a. Market volume, seperti jumlah populasi, pendapatan, leisure time, pendidikan, dan pekerjaan.

b. Cost of travel, seperti harga pelayanan pariwisata yang dipengaruhi oleh inflasi dan nilai tukar, harga pariwisata, jarak, dan waktu.

c. Utility image, seperti daya tarik wisata, publisitas, informasi, cuaca, bahasa, dll. 
Hal yang sama dilakukan oleh Vanhove (1980) yang mendefinisikan empat kelompok variabel penjelas yang saling eksklusif yang memengaruhi permintaan pariwisata internasional:

a. Market element mewakili faktor-faktor yang menentukan jumlah keseluruhan perjalanan

b. Destination element mencakup atribut tujuan yang akan menarik atau menghalangi wisatawan

c. Location element yang menentukan hubungan geografis antara tujuan dan pasar

d. Ties element mencakup faktor-faktor yang mewakili bisnis, budaya, dan hubungan lainnya antar negara.

Sisi permintaan pariwisata telah banyak menjadi fokus penelitian, sedangkan sisi supply (penawaran) atau produksi relatif belum banyak diteliti. Sisi penawaran pariwisata adalah kombinasi dari faktor alam, situs rekreasi, akses, dan aktivitas bisnis sektor swasta sebagai penyedia yang memenuhi tuntutan perjalanan yang berbasis pariwisata (Marcouiller \& Prey, 2005).

Sebelum melakukan perjalanan wisata, wisatawan melakukan proses pengambilan keputusan perjalanan. Proses ini lebih dipengaruhi oleh pengalaman serta kualitas barang dan layanan karena tidak memungkinkan untuk mengukur produk pariwisata sebelum menikmatinya (Maser \& Weiermair, 1998). Karena itu, perjalanan wisata yang dilakukan wisatawan mengandung unsur risiko ketidakpastian. Dengan pencarian informasi terkait perjalanan, wisatawan berusaha mengurangi ketidakpastian yang ada untuk mengingkatkan kualitas perjalanan (Fodness \& Murray 1997).

Unsur risiko yang mungkin bisa dihadapi oleh wisatawan dalam perjalanannya antara lain serangan teroris, masalah transportasi dan akomodasi, kekacauan politik maupun ketidakpuasan dengan pengalaman perjalanan (Maser \& Weiermair, 1998). Roehl \& Fesenmaier (1992), mengelompokan tiga jenis risk taker dalam perilaku perjalanan wisatawan yaitu: kelompok risk taker yang menekankan risiko tempat (place risk), risiko fungsional (functional risk), dan kelompok risiko netral (risk neutral group).

\section{Penelitian Sebelumnya}

Cai \& Lehto (2001) dalam penelitiaannya Profilling the US Bound Chinese Travelers by Purpose of Trip menggunakan variabel-variabel demografi umur, jenis kelamin, pendapatan, dan pekerjaan serta faktor psikografis seperti waktu persiapan perjalanan, sumber informasi, lama tinggal, pola pengeluaran, penggunaan paket wisata, tingkat partisipasi aktivitas wisata, dan tujuan perjalanan. Dalam penelitian tersebut, Cai membandingkan wisatawan asal Cina yang mengunjungi US berdasarkan tujuan perjalanan yaitu bisnis, bisnis dan wisata, dan wisata dan memetakan profile wisatawannya menurut demografi, persiapan sebelum melakukan perjalanan (pre-trip preparation), dan karakteristik perjalanannya.

Faktor sosioekonomi dalam hal ini umur, pendapatan, pendidikan, jumlah anggota keluarga, juga diperhitungkan sebagai faktor yang berpengaruh dalam partisipasi pariwisata yang berbasis alam di Lousiana seperti yang telah dikemukakan oleh Luzar, Diagne, Gan, \& Henning (1995) dalam penelitian Profilling the Nature Based Tourist: A Multinomial Logit Approach. Faktor psikografis juga dimasukan dalam penelitian Luzar tersebut melalui variabel NEP ( New Ecological Paradigm) (Dunlap, Van Liere, Mertig, Catton, \& Howoell, 1992) untuk mengukur environmental attitude responden. Hasil dari penelitian Luzar mengindikasikan responden yang berasal dari kelompok berpenghasilan tinggi (upper-income group) belum menjadikan green tourism sebagai pilihan aktivitas wisatanya dan aktivitas promosi yang dilakukan belum mencapai taget tersebut. 


\section{METODE}

Untuk mendapatkan persepsi yang sama, diperlukan penjelasan mengenai konsep mengenai kegiatan wisata, wisatawan dan wisatawan mancanegara. Passenger Exit Survey yang dilakukan Kementerian Pariwisata mengambil konsep-konsep yang diadaptasi dari International Recommendations Tourism Statistics dan UU no. 10 tahun 2009 tentang Kepariwisataan (Kementerian Pariwisata, 2012 \& 2013).

Berdasarkan konsep-konsep acuan yang disebutkan dalam Pessenger Exit Survey tahun 2012 dan 2013, ada beberapa definisi untuk memperoleh penyamaan persepsi dari penelitian ini yaitu: (Kementerian Pariwisata, 2012 \& 2013)

a. Wisata adalah kegiatan perjalanan yang dilakukan oleh seseorang atau sekelompok orang dengan mengunjungi tempat tertentu untuk rekreasi, pengembangan pribadi, atau mempelajari keunikan daya tarik wisata yang dikunjungi.

b. Wisatawan adalah orang yang melakukan kegiatan wisata.

c. Wisatawan mancanegara adalah seseorang yang bertempat tinggal di luar wilayah Indonesia yang berkunjung ke Indonesia selama tidak lebih dari 1 tahun, untuk segala maksud kunjungan kecuali untuk bekerja atau memperoleh pendapatan/penghasilan di Indonesia.

Peneltian ini menggunakan metode kuantitatif (quantitative research) dengan menggunakan data survei "Pendataan Profil Wisatawan Mancanegara" tahun 2012-2013 yang dimiliki oleh Kementerian Pariwisata. Kriteria yang digunakan untuk melakukan seleksi sample yaitu berusia 15 tahun ke atas, bukan penumpang transit, pengguna paket tour (dibatasi untuk mengetahui pengeluaran wisman), lama kunjungan kurang dari 90 hari, dan maksud kunjungan bukan untuk bekerja dengan menggunakan metode simple random sampling (Kementerian Pariwisata, 2012, 2013).

Survei ini dilakukan di 10 pintu keluar di seluruh Indonesia. Akan tetapi, karena keterbatasan dalam akses data, sample yang digunakan dalam penelitian ini hanya berasal dari 2 lokasi survei dari total 10 lokasi pendataan yaitu Soekarno Hatta (Jakarta) dan Ngurah Rai (Bali) yang merupakan 2 pintu masuk yang menyumbang wisman terbesar. Selain itu, dua pintu masuk tersebut memiliki konektivitas langsung melalui penerbangan internasional dibandingkan pintu masuk yang lain.

Tabel 1. Banyaknya Sampel Pada Pendataan Tahun 2012-2013

\begin{tabular}{ll}
\hline Tahun & Jumlah sample \\
\hline 2012 & 12.156 \\
2013 & 13.150 \\
& \\
\hline Total & 25.306 \\
\hline
\end{tabular}

Sumber: data diolah

Data hasil survei tersebut diolah menggunakan model analisis binomial logistik. Model binomial logistik merupakan suatu kerangka kerja yang sesuai untuk analisis pilihan rekreasi biner seperti partisipasi dalam dua kegiatan pariwisata yang berbeda (Stynes dan Peterson 1984). Dalam penelitian ini binomial logistik melibatkan 2 pilihan/kondisi yaitu Bali (0) dan non Bali (1). Proses mengkategorikan kondisi tersebut berdasarkan provinsi yang dikunjungi wisatawan mancanegara di Indonesia. Wisatawan yang hanya mengunjungi Bali akan diberi nilai 0 dan wisatawan yang mengunjungi Bali dan wilayah lainnya akan diberi nilai 1. Selanjutnya, dari hasil pengelompokan tersebut akan dilihat karakteristiknya (sesuai variabel yang diujikan) dan hubungannya dengan keputusan mengunjungi Bali dan non Bali. 


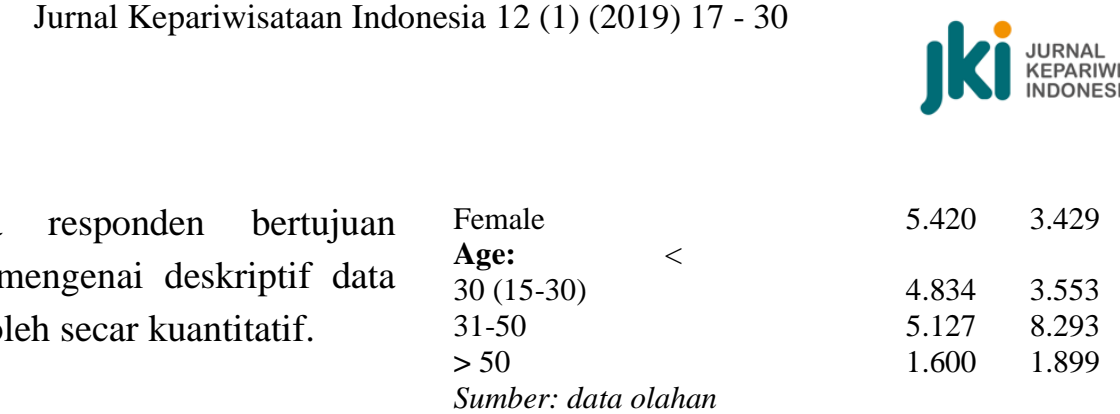

Tabel 2. Deskriptif Data Wisman

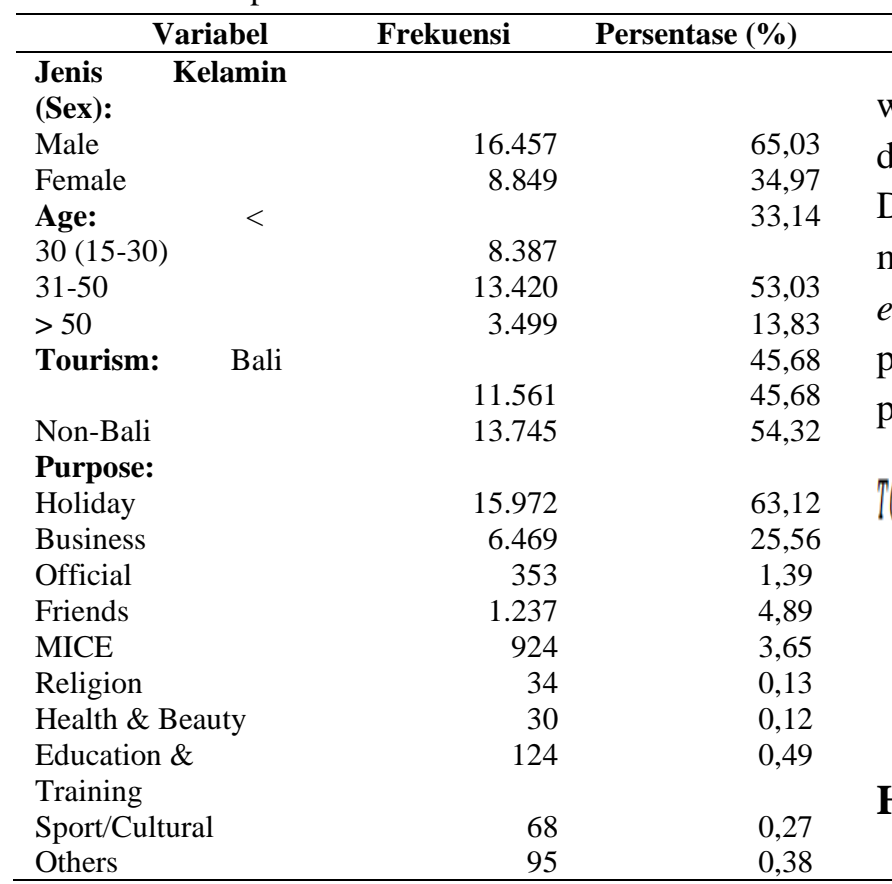

Sumber: data olahan

Berdasarkan tabel di atas, dapat diketahui dominasi turis mancanegara adalah berjenis kelamin pria dengan jumlah prosentase sebesar $65,03 \%$ dan sisanya sebesar $34,97 \%$ adalah turis mancanegara wanita. Data pada tabel di atas juga menunjukkan dominasi wisman berusia antara rentang 31-50 tahun dengan jumlah prosentase sebesar 53,03\%, dan tujuan wisman rata-rata adalah untuk berlibur $(63,12 \%)$ dan bisnis $(25,56 \%)$.

Tabel 3. Tabulasi Silang Data Wisman

\begin{tabular}{lll}
\hline \multicolumn{1}{c}{ Variabel } & Bali & Non Bali \\
\hline Jenis Kelamin & & \\
Male & 6.141 & 10.316
\end{tabular}

wisatawan mancanegara yang mengunjungi destinasi non-Bali berdasarkan penelitian Luzar, Diagne, Gan, \& Henning (1995) yang mencoba melakukan tourist profiling untuk wisata ecotourism di Lousiana. Dengan mengadaptasi penelitian tersebut, model yang digunakan dalam penelitian ini adalah sebagai berikut:

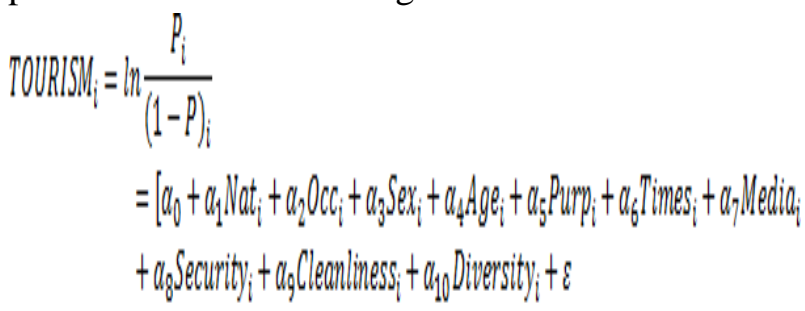

\section{HASIL DAN PEMBAHASAN}

Penelitian ini menggunakan dua model estimasi. Model pertama penelitian ini menyertakan tujuan kunjungan bisnis dan dinas. Model kedua, tidak menyertakan tujuan kunjungan bisnis dan dinas. Hal ini dilakukan untuk mengetahui apakah destinasi non-Bali dalam hal ini wisman yang masuk melalui pintu (Soekarno Hatta) Jakarta lebih dominan untuk tujuan bisnis atau sudah menjadi salah satu pilihan destinasi wisata untuk berlibur. 
Jurnal Kepariwisataan Indonesia 12 (1) (2019) 17 - 30

Tabel 4 Hasil Analisis Pola Kunjungan Wisatawan Mancanegara

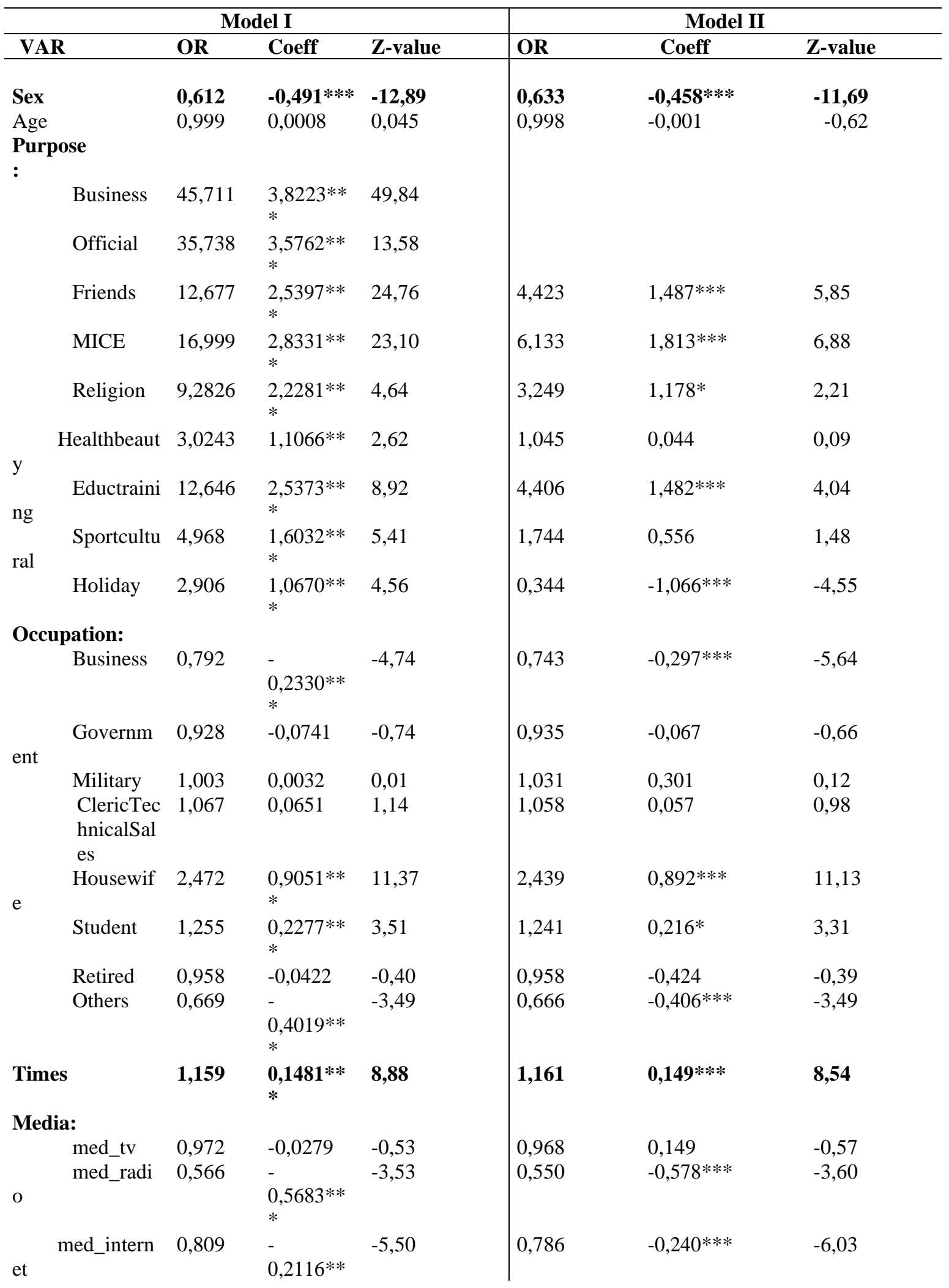


P-ISSN: $1907-9419$

E-ISSN: 2685 - 9076

September 2019
Jurnal Kepariwisataan Indonesia 12 (1) (2019) 17 - 30

JURAL

KEPARIWISATAAN INDONESIA

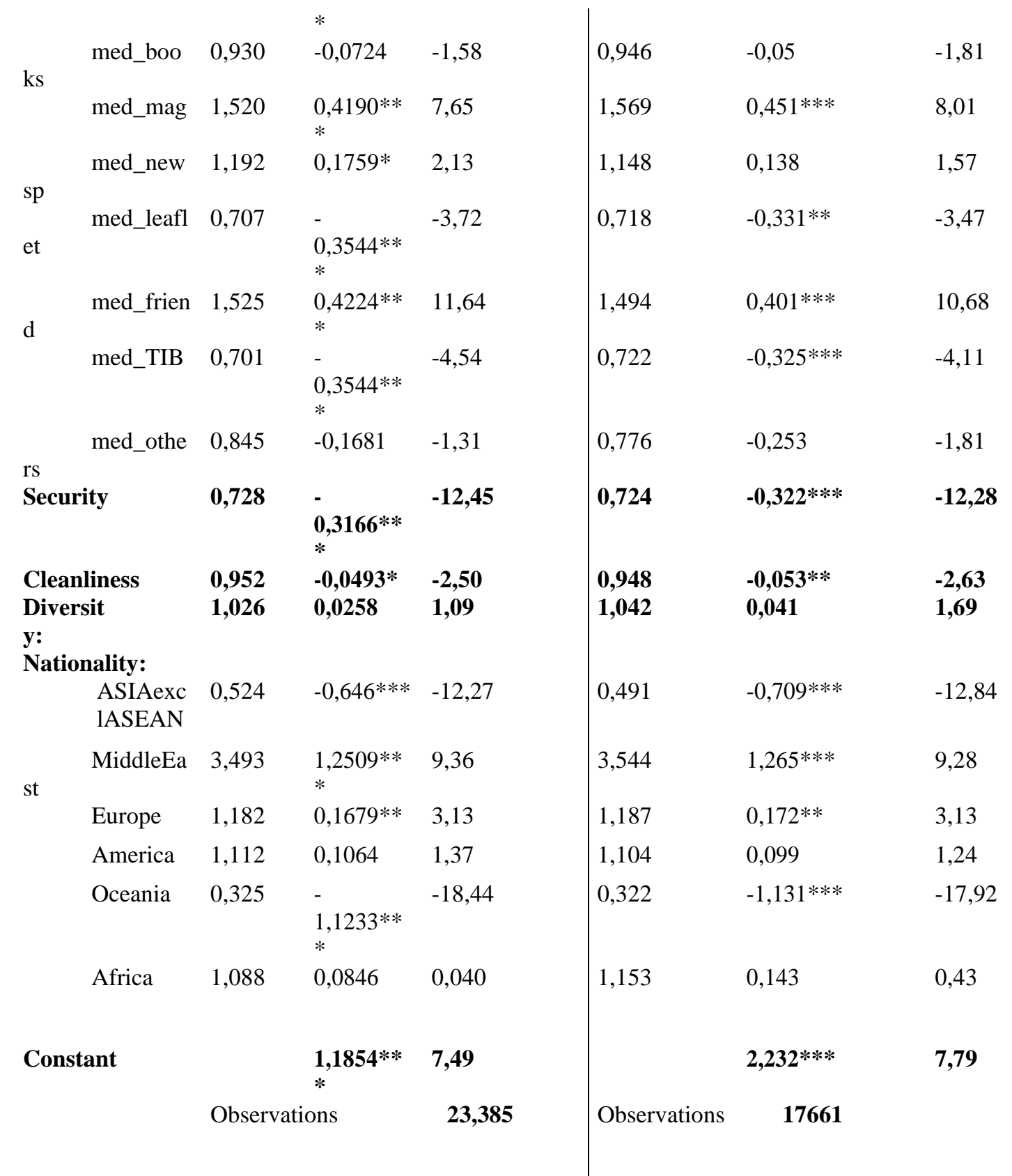

Ket: $*=$ level signifikansi 5\% $(0,05) ; * *=$ level signifikansi $1 \%(0,01) ; * *$ level signifikansi 0,001

Model I dan II tidak menunjukan perbedaan yang signifikan. Beberapa persamaan dalam model I dan model II adalah sebagai berikut.

\section{Faktor demografis}

Menurut Kahle \& Madrigal (1994), faktor demografis akan berpengaruh signifikan terhadap signifikan terhadap keputusan wisata dalam memilih pola kunjungan. Hal ini berkaitan dengan adanya nilai-nilai personal yang dimiliki oleh 
wisatawan latar belakang tertentu, dalam hal ini adalah faktor demografis. Faktor demografis yang dimasukkan dalam penelitian ini adalah variabel jenis kelamin (sex), umur (age), kebangsaan (nationality), dan negara tempat tinggal (COR).

Variabel kebangsaan dan negara tempat tinggal telah diuji multikolinearitas, dan hasilnya ada korelasi yang tinggi antar variabel kebangsaan dan negara tempat tinggal. Untuk itu, penelitian ini memutuskan untuk hanya menggunakan variabel kebangsaan untuk penyamaan penghitungan wisman yang berdasarkan kebangsaan. Model I dan II menunjukan bahwa jenis kelamin memengaruhi keputusan wisatawan dalam menentukan pola kunjungan. Hasil penelitian menujukkan bahwa wisatawan wanita lebih memilih mengunjungi Bali sedangkan wisatawan mancanegara pria lebih memilih non-Bali (selain bali) hal tersebut dapat dilihat pada arah hubungan yang negatif.

Hasil tersebut dikuatkan dengan hasil tabulasi silang (Tabel 3) antara variabel jenis kelamin dan tourism. Wisman wanita yang berkunjung ke Bali terdapat $5.420(61,25 \%)$ dari total data yang diperoleh sejumlah 8.849 wisman berjenis kelamin wanita yang berkunjung ke Indonesia, sedangkan wisman pria lebih dominan memilih destinasi non-Bali sebanyak 10.316 $(62,68 \%)$ dari total wisman pria sejumlah 16.457 yang berkunjung ke Indonesia. Hal tersebut memberikan gambaran bahwa wisman pria lebih cenderung memilih destinasi non-Bali.

Variabel yang menunjukan demografis lainnya adalah usia. Dalam penelitian ini, usia wisatawan mancanegara tidak berpengaruh signifikan terhadap pola kunjungan wisman. Hal tersebut dapat dilihat pada perolehan nilai $\mathrm{Z}_{\text {hitung }}$ sebesar 0,045 dengan nilai signifikansi sebesar $0,654>0,05$. Dari hasil tabulasi silang variabel usia dan tourism, rata-rata usia wisman terbanyak yang berkunjung ke Indonesia berada pada rentang usia 31-50 tahun dengan jumlah sebesar 8.293 memilih berkunjung ke destinasi non-Bali dan 5.127 memilih destinasi Bali. Sedangkan wisman pada usia < 30 tahun lebih cenderung memilih Bali sebagai tempat destinasi kunjungan mereka.

Berdasarkan variabel latar belakang pekerjaan wisman, hasilnya bervariasi. Hasilnya juga tidak terlalu berbeda antara model I dan II. Wisman yang memiliki pekerjaan sebagai pebisnis, ibu rumah tangga, pelajar, dan pekerjaan lainnya berpengaruh signifikan terhadap pola kunjungan wisman dalam menentukan destinasi yang dituju. Hal tersebut dapat dilihat pada perolehan nilai $z_{\text {hitung }}>1,96$ atau nilai signifikansi $<0,05$. Wisman yang memiliki latar belakang pekerjaan sebagai pekerja pemerintahan, militer, cheric/technical/sales, dan pensiunan tidak berpengaruh signifikan terhadap pola kunjungan tempat destinasi yang akan dikunjungi.

Untuk variabel kebangsaan, peneliti mengelompokan berdasarkan regional. Temuan penelitian untuk variabel ini juga tidak menunjukan perbedaan yang berarti jika dibandingkan dari model I dan II. Temuan penelitian menunjukkan wisman yang berasal dari Timur Tengah (middle east) dan Eropa lebih memilih destinasi non Bali ketika berkunjung ke Indonesia. Negara Asia dan Oceania yang cenderung signifikan memilih Bali sebagai tempat destinasi mereka. Wisman Amerika dan Afrika, hasil temuan tidak menunjukkan signifikansi dalam pemilihan destinasi.

\section{Faktor Psikografi}

Selain faktor demografi, nilai-nilai personal juga dipengaruhi oleh faktor psikografis sehingga nantinya akan membentuk perilaku (Kahle \& Madrigal, 1994). Faktor psikografis bisa dilihat dari motivasi (tujuan), perilaku, dan nilainilai yang dipercaya oleh individu (Veisten, 2015). Dalam penelitian ini, faktor psikografis yang 
mempengaruhi keputusan wisatan dalam memilih destinasi kunjungan akan dilihat melalui variabel tujuan berkunjung (purpose), berapa kali berkunjung (times), dan perilaku wisman dalam menggunakan media yang mempengaruhi keputusan meraka untuk memilih destinasi kunjungan ke Indonesia.

Variabel tujuan berkunjung ini memiliki perbedaan yang signifikan antara model I dan model II. Pada model I, wisman yang berkunjung ke Indonesia, berdasarkan tujuannya, seluruh tujuan memiliki pengaruh signifikan terhadap pola kunjungan wisman dalam menentukan destinasi yang dituju. Hal tersebut dapat dilihat pada perolehan nilai $\mathrm{Z}_{\text {hitung }}>1,96$ atau nilai signifikansi $<0,05$, hal ini menunjukkan bahwa wisatawan mancanegara yang memiliki tujuan, baik untuk: berlibur, bisnis, official, mengunjungi teman, keagamaan, dan tujuan lainnya sangat mempengaruhi terhadap pola kunjungan wisman dalam menentukan tempat destinasi yang akan dituju, dengan tujuan terbanyak wisman adalah untuk berlibur dan berbisnis. Setiap tujuan kunjungan menunjukan kecenderungan wisatawan memilih destinasi non Bali.

Pada model II, setelah menghapuskan tujuan berkunjung bisnis official untuk menghindari adanya bias, terdapat perubahan yang signifikan. Pada model II, tujuan berkunjung health and beauty dan sport cultural tidak berpengaruh signifikan terhadap pemilihan destinasi. Hasil yang berbeda juga ditunjukkan pada tujuan berkunjung holiday/leisure. Wisatawan yang memiliki tujuan holiday/leisure secara signifikan cenderung memilih Bali sebagai destinasi yang dikunjungi. Hal ini membuktikan bahwa Bali masih menjadi pilihan wisatawan mancanegara untuk berlibur. Destinasi non Bali masih kalah bersaing sebagai destinasi liburan di pasar wisatawan mancanegara.
Berapa kali wisatawan berkunjung ke Indonesia (times) berpengaruh signifikan terhadap pola kunjungan wisman dalam menentukan destinasi yang dituju. Hal tersebut dapat dilihat pada perolehan nilai $Z_{\text {hitung }}$ sebesar 8,88 dengan nilai signifikansi sebesar $0,000<0,05$, hal ini menunjukkan bahwa wisatawan mancanegara yang sudah pernah mengunjungi Indonesia cenderung memilih destinasi non-Bali sebagai tempat destinasi yang akan mereka kunjungi. Nilai OR sebesar 1,159 menunjukkan bahwa wisatawan yang sudah pernah berkunjung ke Indonesia akan lebih memilih destinasi non-Bali 1 kali lipat dibandingkan wisatawan mancanegara yang belum pernah mengunjungi Indonesia. Hal tersebut menunjukkan bahwa Bali tetap menjadi salah satu tempat tujuan utama mereka untuk berkunjung ke Indonesia. Telah dijelaskan bahwa keputusan wisata dalam hal ini pemilihan destinasi, berkaitan dengan risiko dan ketidakpastian. Berdasarkan hasil analisis yang telah dilakukan, risk neutral group ditunjukan bahwa wisatawan non Bali merupakan repeater yang sudah beberapa kali mengunjungi Indonesia. Wisatawan repeater ini cenderung sudah pernah mengunjungi Bali dan memerlukan pilihan destinasi lain.

Media informasi yang memiliki pengaruh signifikan dalam mempengaruhi pola kunjungan wisman pada tempat destinasi selain Bali adalah media majalah, leaflet, radio, koran, dan melalui informasi teman dengan nilai signifikansi $<0,05$. Temuan hasil penelitian justru media televisi, buku, dan media lainnya tidak berpengaruh signifikan terhadap pola kunjungan wisman dalam berkunjung ketempat destinasi di Indonesia ( $p$ $>0,05$ ).

Temuan hasil penelitian menunjukkan bahwa media majalah, leaflet, radio, koran, internet dan melalui informasi teman dapat memberikan pengaruh pada wisman untuk 
mengunjungi tempat destinasi selain Bali. Informasi dari selain Bali. Informasi dari mediamedia tersebut memiliki peran yang cukup dipercaya wisman untuk mengunjungi tempat destinasi lainnya di Indonesia.

Temuan penelitian juga menunjukkan di antara semua media yang memiliki peran besar untuk memberikan informasi tempat destinasi selain Bali adalah informasi dari teman, lalu diikuti oleh media informasi majalah, dan internet. Banyak penelitian yang menemukan hasil bahwa efek dari word of mouth pada penelitian tourism berhubungan dengan perilaku kunjungan wisatawan baik mancanegara maupun wisatawan domestik. Penelitian Jalilvand \& Samiei (2012) menunjukkan bahwa komunikasi WOM online memiliki dampak signifikan pada sikap terhadap kunjungan ke Isfahan, norma subyektif, persepsi kontrol perilaku, dan niat untuk bepergian. Selain itu, pengalaman perjalanan memiliki dampak yang signifikan dalam menggunakan konstruksi eWOM dan TPB (Testing the theory of planned behavior. Menurut penelitian yang dilakukan Albarq (2016) menunjukkan bahwa komunikasi e-WOM berdampak positif terhadap niat perjalanan wisatawan dan sikap mereka terhadap Yordania sebagai tujuan, sementara efek positif ditemukan untuk sikap terhadap kunjungan Jordan pada niat mereka untuk bepergian. Manajer agen perjalanan dapat mempertimbangkan berbagai aspek e-WOM untuk mendorong wisatawan berpartisipasi dalam komunitas perjalanan online dan membangun komunitas seperti itu, karena ini akan menumbuhkan kepercayaan dalam hal mengunjungi Jordan.

\section{Opini wisatawan mancanegara}

Opini wisatawan dalam terhadap pariwisata Indonesia menjadi salah satu variabel untuk mengetahui aspek mana yang menjadi kekuatan destinasi Indonesia dan menjadi bahan perbaikan untuk memperbaiki kualitas destinasi. Aspek-aspek yang dimasukan dalam penilaian pariwisata Indonesia adalah aspek keamanan (security), keselamatan (safety), kebersihan (cleanliness), dan keberagaman atraksi (diversity).

Factor keamanan (security) dan kebersihan (cleanliness) menjadi salah satu factor yang menyebabkan Bali masih menjadi destinasi tujuan wisman dibandingkan destinasi non Bali. Factor diversity (keberagaman atraksi) tidak memiliki pengaruh yang signifikan dalam menentukan pola kunjungan wisman. Apabila penilaian pariwisata Indonesia akan semakin baik dari aspek keamanan dan kebersihan, wisatawan akan cenderung tertarik mengunjungi Bali. Hal ini masih berkaitan dengan image Bali sebagai destinasi wisata Indonesia yang telah berhasil menembus pasar internasional sehingga ketika penilaian pariwisata Indonesia meningkat, Bali akan menjadi destinasi utama yang ingin dikunjungi oleh wisatawan.

\section{SIMPULAN}

Indonesia memiliki potensi pariwisata yang sangat besar. Potensi ini tersebar di hampir seluruh wilayah Indonesia. Akan tetapi, sampai saat ini pariwisata Indonesia hanya identik dengan Bali. Pengembangan destinasi lain selain Bali (destinasi non-Bali) telah mulai berlangsung di hampir seluruh wilayah Indonesia karena potensi ekonomi pariwisata yang bisa mendorong perekonomian wilayah.

Walaupun belum sebanyak Bali, wisatawan mancanegara telah mengunjungi destinasi non-Bali. Hal ini membuktikan destinasi non-Bali juga berpotensi untuk dikembangkan karena adanya permintaan pariwisata dari wisatawan. Penelitian ini bertujuan membuat profil wisatawan mancanegara untuk destinasi non-Bali sebagai salah satu langkah pengembangan pemasaran pariwisata. 
Berdasarkan analisis yang telah dilakukan menggunakan data PES 2012-2013 yang diambil dari 2 pintu utama yaitu Soekarno Hatta, Jakarta dan Ngurah Rai, Bali, wisatawan yang mengunjungi destinasi non-Bali lebih dominan laki-laki dan merupakan repeater. Berdasarkan kebangsaan, wisatawan Timur Tengah dan Eropa lebih tertarik mengunjungi destinasi non Bali. Hasil penelitian juga menunjukan adanya potensial market dari kalangan ibu rumah tangga dan pelajar.

Berdasarkan profil wisatawan tersebut, beberapa pengembangan pemasaran pariwisata yang bisa dilakukan adalah peninjauan kembali promosi pariwisata mancanegara. Hasil penelitian menunjukkan adanya kecenderungan wisatawan mancanegara yang berkunjung ke destinasi non Bali menjadikan majalah dan informasi teman (worth of mouth) sebagai sumber informasi yang mempengaruhi keputusan wisata dari para wisatawan. Promosi yang diperlukan lebih spesifik ke Timur Tengah dan Eropa yang memiliki preferensi ke destinasi non-Bali. Mayoritas wisman yang mengunjungi destinasi non-Bali merupakan repeater.

Untuk wisatawan yang mengunjungi hanya mengunjungi Bali, memiliki cenderung memiliki profile sebagai berikut: berjenis kelamin wanita, berasal dari Asia dan Oceania, dan cenderung first timer. Wisman yang berkunjung cenderung berprofesi sebagai bussinessman dan memiliki tujuan berkunjung untuk liburan.

Bali sebagai destinasi utama pariwisata Indonesia bisa dimanfaatkan untuk menjaring wisman ke destinasi lain dengan melakukan promosi destinasi non-Bali untuk menjaring wisman yang telah mengunjungi Bali. Dengan demikian wisman memiliki alternatif lain jika berkunjung ke Indonesia kembali.

\section{DAFTAR PUSTAKA}

\section{$\underline{\text { Buku }}$}

Badan Pusat Statistik. (2018). Statistik Kunjungan Wisatawan Mancanegara 2017. Badan Pusat Statistik: Subdirektorat Statistik Pariwisata.

Kementerian Pariwisata. Statistik Profil Wisatawan Mancanegara Tahun 2012. (2012). Kementerian Pariwisata: Pusat Data dan Informasi.

Kementerian Pariwisata. Statistik Profil Wisatawan Mancanegara Tahun 2013. (2013). Kementerian Pariwisata: Pusat Data dan Informasi.

Kementerian Pariwisata. Rencana Strategis Kementerian Pariwisata 2015-2019. (2015). Kementerian Pariwisata: Sekretariat Kementerian.

Ministry of Tourism.(2017). Statistical Report on Visitor Arrivals to Indonesia 2016. Ministry of Tourism: Deputy Assistant for Research and Development on Tourism Policy.

Tantowi, Akhmad, Baruddin, dan Suryani, Endang. NESPARNAS : Neraca Satelit Pariwisata Nasional 2017. Kementerian Pariwisata: Deputi Bidang Pengembangan Kelembagaan Kepariwisataan

Peraturan Pemerintah No.50 tahun 2011. Rencana Induk Pembangunan Pariwisata Nasional 20102025. 2 Desember 2011. Lembaran Negara Republik Indonesia Tahun 2011 Nomor 125. Jakarta.

\section{$\underline{\text { Jurnal }}$}

Albarq, A. (2016). Measuring the Impacts of Online Word-of-Mouth on Tourists , Attitude and Intentions to Visit Jordan : An Empirical Study Measuring the Impacts of Online Word-of-Mouth on Tourists 'Attitude and Intentions to Visit Jordan : An Empirical Study, (December 2013). https://doi.org/10.5539/ibr.v7n1p14

Cai, L. A., \& Lehto, X. Y. (2013). Journal of Hospitality \& Leisure Profiling the U .S . -Bound Chinese Travelers by Purpose of Trip, (August). https://doi.org/10.1300/J150v07n04

Donzelli, M. (2010). Journal of Air Transport Management The effect of low-cost air transportation on the local economy: Evidence 
from Southern Italy. Journal of Air Transport Management, 16(3), 121-126. https://doi.org/10.1016/j.jairtraman.2009.07.005

Dunlap, R. E., K. D. Van Liere, A. G. Mertig, W. R. Catton, and R. E. How- ell (1992). "Measuring Endorsement of an Ecological Worldview: A Revised NEP Scale." Paper presented at the Annual Meeting of Rural Sociology, October, Snowbird, Utah.

Fodness, D., \& Murray, B. (1997). Tourist Information Search. Atzrzals of Tourisin Research, 24(3): 503523.

Jalilvand, M. R., \& Samiei, N. (2012). The impact of electronic word of mouth on a tourism destination choice, 22(5), 591-612. https://doi.org/10.1108/10662241211271563

Kahle, L. R., \& Madrigal, R. (1994). Predicting vacation activity preferences on the basis of valuesystem segmentation. Journal of Travel Research, (winter), 22-28.

Kamakura, W. A., \& Mazzon, J. A. (1991). Value segmentation: A model for the measurement of values and value systems. Journal of Consumer Research, 18, 208-218.

Kamakura, W. A., \& Novak, T. P. (1992). Valuesystem segmentation: Exploring the meaning of LOV. Journal of Consumer Research, 19(1), 119131.

Keintz, Rita M. (1968). "A Study of the Demand for International Travel to and from the United States." In the Proceedings of the 10th Conference of the Western Council for Travel Research. Western Council for Travel Research, pp. 59-69.

Luzar, E. J., Diagne, A., Gan, C. E. C., \& Henning, B. R. (1995). Profiling the Nature-Based Tourist : A Multinomial Logit Approach, (1993). Journal of Travel Research. Vol.36, August 1998, 48-55.

Marcouiller, D. W., \& Prey, J. (2014). The Tourism Supply Linkage: Recreational Sites and their Related Natural The Tourism Supply Linkage: Recreational Sites and their Related Natural Amenities, (January 2005).

Maser, Birgit \& Klaus Weiermair. (1998). Travel Decision-Making: From the Vantage Point of Perceived Risk and Information Preferences. Journal of Travel \& Tourism Marketing, 7:4, 107121, DOI: 10.1300/J073v07n04_06
Mckercher, B., \& Hui, E. L. L. (n.d.). Journal of Travel \& Tourism Terrorism, Economic Uncertainty and Outbound Travel from Hong Kong, (July 2013), 37-41. https://doi.org/10.1300/J073v15n02

Mehmetoglu, M., Hines, K., Graumann, C., \& Greibrokk, J. (2010). The relation- ship between personal values and tourism behavior: A segmentation approach. Journal of Vacation Marketing, 16(1), 17-27.

Mikulicz, Hans (1983). "Determinants of Tourism Flows in Europe." In Semi- nar on the Importance of Research in the Tourism Industry, Helsinki, Finland, June 8-11, 1983. European Society For Opinion and Marketing Research, pp. 7-16.

Muller, T. E. (1991). Using personal values to define segments in an international tourism market. International Marketing Review, 8(1), 5-70.

Ramkissoon, H., Uysal, M., \& Brown, K. (2011).Journal of Hospitality Marketing \& Relationship Between Destination Image and Behavioral Intentions of Tourists to Consume Cultural Attractions, (December 2014), 3741.https://doi.org/10.1080/19368623.2011.570648

Roehl, W. S. (1988). "A Typology of Risk in Vacation Travel." Unpub- lished Ph.D. diss. Texas A\&M University, College Station.

Stynes, D. J., and G. L. Peterson (1984). "A Review of Logit Models with Implications for Modeling Recreational Choices." Journal of Leisure Research, 16: 295-310.

Tang, C. F., \& Tan, E. C. (2015). Does tourism effectively stimulate Malaysia's economic growth? Tourism Management, 46, 158-163. https://doi.org/10.1016/j.tourman.2014.06.020

Tkaczynski, A., Rundle-Thiele, S. R., \& Beaumont, N. (2009). Segmentation: A tourism stakeholder view. Tourism Management, 30(2), 169-175. https://doi.org/10.1016/j.tourman.2008.05.010

Vanhove, N. (1980). "Forecasting in Tourism." The Tourist Review, 3: 2-7

Veisten, K. (2015). Tourist Segments for New Facilities in National Park Areas : Profiling Tourists in Norway Based on Psychographics and Demographics, (0349), 486-510. https://doi.org/10.1080/19368623.2014.911713

Veisten, K., Lindberg, K., Grue, B., \& Haukeland, J. V. (2014). The role of psychographic factors in 
naturebased tourist expenditure. Tourism

Economics, 20(2), 301-321.

https://doi.org/10.5367/te.2013.0281

\section{Sumber Online}

Kementerian Pariwisata. Ranking Devisa Pariwisata Terhadap 11 Ekspor Barang Terbesar Tahun 2011-2015.

http://www.kemenpar.go.id/userfiles/devisa20112015.pdf diakses 3 Januari 2019.

Kementerian Pariwisata. Paparan- Deputi BPDIP : Pembangunan Destinasi Pariwisata Prioritas 2016-2019.

http://www.kemenpar.go.id/userfiles/Paparan\%20\%20Deputi\%20BPDIP.pdf diakses tanggal 4 Januari 2019.

World Bank. (2018). International tourism, number of arrivals.

https://api.worldbank.org/v2/en/indicator/ST.INT. ARVL?downloadformat=excel diakses tanggal 7 November 2018.

World Travel \& Tourism Council. Travel \& Tourism Global Economic Impact \& Issues 2017. (2017). www.wttc.org 